\title{
Editorial
}

The readers' attention is drawn to the Publishers Notes, which contain information about "a most important recent discovery of Hegel's lectures on the philosophy of right, the Heldelberg Lectures of $1817 / 18$ - the earliest version of The Philosophy of Right - and to the proposal for an Anglo-German seminar to discuss them prior to German publication.

\section{Announcements and Reports}

'The Meaning of Absolute Spirit': Bilingual Symposium at the University of Ottawa, November 6-8, 1981

The organising committee of the symposium consisted of Prof. J.W. Burbldge (Trent Univ.), B. Garceau (Ottawa), T.F. Geraets (Ottawa) and M. Kaufmann (Univ. du Québec a Trols Rivieres).

According to the original announcement the programme included the following main papers: H.S. Harris (Toronto), The OrIgin and Development of Hegel's Concept of Absolute Spirit; Remo Bodel (Pisa), La transition de l'esprit objectif a l'esprit absolu; H.-G. Gadamer (Heidelberg and Boston). The Absoluteness of Absolute Spirit and Art; L. Dupre (Yale), Le caractere absolu de l'esprit absolu et la religion; P.J. Labarrière (Paris), Savoir absolu et Esprit absolu; K. Schmitz (Toronto), Absolute Idea and Absolute Spirit; P. Ricoeur (Paris and Chicago), Le discours sur l'Esprit absolu.

Thosewishing for more information about the proceedings of the symposium may be able to obtain it by writing to:

Prof. Theodore F. Geraets, Département de Philosophie, Université d'ottawa, 90 rue Wilbrod, Ottawa, Ont. K1N 6N5, Canada.

\section{Hegel and Kant Annlversarles in the U.S.S.R.}

Last year's colncidence of the 150th anniversary of Hegel's death with the bicentenary of publication of Kant's Critique of Pure Reason, which occasioned vartous events in the west, has been noted in this bulletin. Recent issues of Voprosi Filosofil, a monthly journal issued by the Moscow Institute of philosophy, show that the anniversaries did not pass unnoticed in the Soviet Union. There are in fact grounds for concluding that an established interpretation of Hegel's philosophy is changing, and that Kant is being studied as more than a precursor of him.

The traditlonal view goes back at least to V.F. Agmus' 